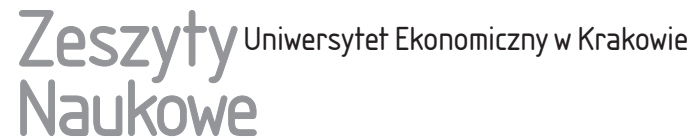

\section{Modlitwa wolności a kontyngencja człowieka w pamiętnikach Etty Hillesum}

\section{Streszczenie}

Doświadczenie wolności, ujmowane na szereg sposobów przez filozofię, psychologię, socjologię, teologię, politykę, ukazuje się jako kategoria w swej specyfice niewyczerpywalna. Na jej złożoność i problematyczność wskazuje nie tylko fakt niezliczonych interpretacji intelektualnych, ale również sposób, w jaki się ją ,zagospodarowuje”. Z rozmaitych prób odsłaniania fenomenu wolności w kontekście przygodności człowieka uwydatnia się droga dialogiczna, która odsłania jeden z ważniejszych rysów tego, czym jest wolność.

Oryginalna refleksja zawarta w pamiętnikach z czasów II wojny światowej (Przerwane życie. Pamiętniki 1941-1943) Etty Hillesum, holenderskiej Żydówki, pokazuje podstawową właściwość wolności, którą jest jej relacyjność, a najgłębszy jej wyraz dokonuje się w kontakcie z Bogiem. Poprzez tę właściwość ukazana jest jednocześnie właściwość samego człowieka, który ma możliwość ukierunkowania siebie na miłość lub nienawiść, na życie lub śmierć, na piękno lub brzydotę, dobro lub zło. Sama Etty Hillesum stawia na afirmację życia jako takiego, a przez relację wertykalną z Bogiem staje się prawdziwą ambasadorką życia, nawet w obliczu ekstremalnego zagrożenia, niesprawiedliwości i okrucieństwa wojny, przy czym życie nie jest traktowane jako dojmująca i uciskająca kontyngencja, ale jako czas kairos, czyli coś do twórczego i pozytywnego wykorzystania, realizowania wartości ogólnoludzkich i stawania się świadkiem życia przepełnionego pierwiastkiem wieczności.

Stąd głównym celem niniejszego studium jest zaprezentowanie kilku podstawowych wątków w opisie człowieka, które zostają wydobyte z autorefleksyjnego sposobu pisania samej autorki pamiętników. Poprzez wniknięcie w opis wewnętrznego świata Hillesum

Inga Mizdrak, Uniwersytet Ekonomiczny w Krakowie, Katedra Filozofii, 31-510 Kraków, ul. Rakowicka 27, e-mail: mizdraki@uek.krakow.pl 
podjęta została próba scharakteryzowania tych elementów w podmiotowości człowieka, które uwydatniają konkretne indywiduum jako zanurzone w relacji do samego siebie, innych i Boga.

Słowa kluczowe: wolność, życie, miłość, Bóg.

Moje serce przypomina śluzę, na którą kieruje się raz po raz nowy strumień wody Etty Hillesum, Przerwane życie. Pamiętniki 1941-1943

\section{Wprowadzenie}

Problematyka wolności w kontekście kontyngencji człowieka wydaje się stanowić jeden z najtrudniejszych obszarów badawczych w dziedzinie antropologii filozoficznej. W sporze o naturę wolności uczestniczyli w zasadzie wszyscy ważniejsi myśliciele od czasów starożytnych aż po dzisiejsze, co oznacza nie tylko, iż fenomen wolności sam w sobie jest pewnego rodzaju niewyczerpywalnym tematem badawczym, ale także że inspiruje do ciągłego odkrywania najgłębszych wymiarów człowieka. Zakładając, iż wolność jest podstawowym doświadczeniem człowieka w świecie, noszącym atrybut wielowymiarowości, nie sposób nie włączyć jej w obszar dociekań z zakresu filozofii, psychologii, socjologii, polityki czy teologii. Skoro każda z wymienionych dziedzin myślenia koncentruje się na odmiennych aspektach wolności i próbuje je w sposób reprezentatywny określić, zarazem potęguje znaczenie i actwo treści, jakie w wolności, poprzez wolność i dzięki niej objawiają to, co w człowieku podmiotowe, oryginalne, niezbywalne.

Inspiracją do napisania niniejszego artykułu była lektura pamiętników z czasów II wojny światowej (polska edycja - Przerwane życie. Pamiętniki 19411943 [2013]) Etty Hillesum, młodej holenderskiej Żydówki, która w geście solidarności z prześladowanymi rodakami dobrowolnie pozwoliła się wywieźć do obozu zagłady w Auschwitz. Dzieło i osoba Etty Hillesum są godne uwagi jako przykład głębokiego humanizmu, altruistycznej drogi do uzyskania dojrzałości duchowej poprzez różnorodny zapis zjawisk zewnętrznych, a głównie przeżyć wewnętrznych $\mathrm{z}$ ich rozmaitymi modi $\mathrm{w}$ aurze wolności intelektualnej.

Etty Hillesum w swoich pamiętnikach ukazuje własne pole doświadczenia wolności, w specyficznej relacji inspiracji płynących z psychoanalizy, filologii klasycznej, filozofii oraz religii judaistycznej z inklinacjami do chrześcijaństwa. Przez opisy swoich doznań wewnętrznych niejako łączy rozmaite ścieżki docierania człowieka do poznania siebie, ale to, co uwydatnia się w lekturze pamiętników, prowokuje do postawienia pytania, na którą z tych dróg stawiała sama autorka. Jej fascynacja psychoanalizą z pewnością pozwalała docierać do głębi 
siebie, ukazywała również sprzeczności w niej tkwiące oraz umożliwiała obserwację i nazwanie szeregu wrażeń, uczuć i przeżyć. Filozofia z kolei uwydatniała przestrzeń intelektualnego ujęcia siebie z różnych perspektyw, pozwalając zarazem na zrobienie następnego kroku w procesie samopoznania, a wykształcenie filologiczne dodawało szerokiego horyzontu kulturowego i humanistycznego jej dociekaniom, kim jest człowiek jako taki. Jednakże dla Etty Hillesum wszystkie te drogi wydają się ważne, aczkolwiek stanowią jedynie tło w procesie docierania do własnego ,ja”, które prawdziwej siły w poznaniu siebie nie czerpało li tylko $\mathrm{z}$ różnych dziedzin myślenia, ale przede wszystkim i chyba na pierwszym miejscu z osobistej relacji z Bogiem. W jej osobistym doświadczeniu to właśnie poszukiwanie relacji wertykalnej z Bogiem staje się prawdziwą linią życia, a inspiracje filozoficzne i te płynące $\mathrm{z}$ psychoanalizy są jedynie kontrapunktem w podjęciu ważnych życiowych decyzji, aż do rezygnacji z własnych marzeń w akcie dobrowolnego poddania się deportacji do Auschwitz.

Zawężenie problematyki wolności do jednej publikacji autorki w zasadzie z góry mogłoby zostać potraktowane jako niefrasobliwość konceptualna lub metodologiczny błąd. Tak złożona kwestia, jaką jest wolność, w kontekście przygodności człowieka wymagałaby ogromnego wysiłku intelektualnego w wykazaniu założeń i przesłanek, wyjaśnienia pojęć oraz ustrukturalizowania wywodu. Nie sposób w tak krótkiej formie tego uczynić, czego autorka niniejszego opracowania ma świadomość. Wydaje się za to, iż warto poświęcić uwagę ciekawej myśli Etty Hillesum, z pewnością inspirującej do dalszych badań, które mogą stać się ważnym przyczynkiem do głębszego zrozumienia jednostki, zarówno w jej wymiarze osobowym, duchowym, moralnym, jak i społecznym.

Niniejszego studium poświęconego oryginalnej myśli Etty Hillesum w zasadzie nie da się zakwalifikować stricte ani do badań z obszaru filozofii religii, antropologii filozoficznej ani mistyki ${ }^{1}$, ale po trosze do każdej z tych dziedzin, zatem i metodologia w próbie odsłonięcia i przybliżenia refleksji autorki pamiętników musi być eklektyczna, co nie powinno przesłaniać wartości wnikliwych analiz jej osobowego ,ja”. Jeśli potraktować formę pamiętników jako żywy obraz utrwalonych przeżyć, przemyśleń i doznań w danym czasie, właśnie taki sposób może okazać się słuszną metodą w dociekaniu prawdy człowieka i jego tęsknoty za tym, by ,usłyszeć niewidzialne” [Tarnowski 2005].

Głos E. Hillesum raczej nie ma ambicji do systemowego ujmowania kondycji człowieka w opisie jego przygodności i natury, ale z pewnością zajmuje ważne, aczkolwiek wciąż mało znane miejsce w tzw. literaturze filozofującej i refleksji

\footnotetext{
${ }^{1}$ Krytycznym i naukowym ujęciem problemu mistyki w Polsce zajmują się m.in: M. Gogacz w książce Filozoficzne aspekty mistyki. Materiały do filozofii mistyki [1985], J.A. Kłoczowski, Drogi człowieka mistycznego [2001], L. Węgrzynowicz, Mistyka kobieca. Hermeneutyczne studium kobiecego doświadczenia Boga [2013].
} 
humanistycznej. Istotnym walorem poszczególnych analiz staje się bowiem przybliżenie tego, kim jest człowiek w horyzoncie trwania na styku racjonalności i piękna życia oraz absurdalności i brzydoty wojny. Stąd głównym przedmiotem niniejszej pracy i zarazem podstawowym celem jest zaprezentowanie kilku podstawowych wątków w opisie człowieka, które zostają wydobyte z autorefleksyjnego sposobu pisania Etty Hillesum. Poprzez wniknięcie w oryginalny sposób przypatrywania się autorki samej sobie podjęta została próba scharakteryzowania takich elementów w podmiotowości człowieka, które być może wyostrzą sposób patrzenia na konkretne indywiduum w perspektywie zarówno jednostkowej, jak $\mathrm{i}$ bycia $\mathrm{z}$ innymi.

\section{Afirmacja życia i twórczej postawy wobec niego}

Etty Hillesum nie jest jedyną kobietą opisującą doświadczenie II wojny światowej z samego jej wnętrza. Jak wielu w tamtym czasie obserwuje rzeczywistość, stawiając pytania o sens i bezsens wszystkiego, co jest, próbując żyć każdym dniem w znoszeniu lęków, trwogi, przekraczaniu siebie, szukaniu pomocy u Boga i harmonii między tym, co wewnątrz, i tym, co na zewnątrz, w odszukiwaniu „podziemnego strumienia”, z którego można by czerpać siły witalno-duchowe. Nie jest także jedynym świadkiem wielu obliczy kontyngencji człowieka zarówno w wymiarze jego przygodności (niekonieczności i znikomości istnienia), jak i swoistej przypadkowości znalezienia się w obozach zagłady. Autorka pamiętników nie jest też kronikarzem, chcącym zarejestrować niezliczoną liczbę szczegółów „życia - nieżycia” człowieka obozowego, wpisanego wbrew własnej woli w irracjonalną logikę zła totalitaryzmu. Jest ona jednak kimś, kto tracąc życie w Auschwitz (a wcześniej pisząc własne przemyślenia w Amsterdamie przed deportacją do Oświęcimia), ukazuje w wyjątkowy sposób niezbywalność (nieredukowalną podmiotowość) pojedynczej osoby ludzkiej, jej podmiotowe szukanie siebie, godność zakorzenioną w Nieskończoności i związaną z nią tęsknotę za Transcendencją oraz rozpaczliwy krzyk o godność innych wobec odrazy niesprawiedliwości, kłamstwa i szyderstwa wojny. Odsłania ona też najważniejsze i niewyczerpywalne pytanie o sens i przejawy ludzkiej natury. Dzięki jej swoistemu stylowi prowadzenia rozmowy z samą sobą czytelnik także ma możliwość odkrywania głębokich pokładów swojej osobowości i wnikania w siebie, we własne procesy myślowe, przez co sama autorka, choć w sposób niezamierzony, staje się dla odbiorcy jakby przewodnikiem w sposobie coraz głębszego poznawania siebie. Chce również świadczyć o tym, o czym należy dać świadectwo, ma zamiar zatem oddzielić to, co w życiu nie jest najważniejsze, i zaświadczać o tym, co w samym życiu jawi się jako jego najgłębsza istota. Jej największym bodaj 
pragnieniem, związanym z wiernością wobec miłości życia i miłości do innych, było stanie się „myślącym sercem baraku”, a nawet „myślącym barakiem całego obozu koncentracyjnego" [Hillesum 2013, s. 212], gdyby miała tam trafić.

Na czym miałaby polegać unikatowość refleksji holenderskiej Żydówki, świadczy choćby jej metafizyczno-filozoficzno-etyczno-literacka narracja, przeplatająca wątki z osobistego i intymnego życia z uniwersalną refleksją nad kondycją ludzką i afirmatywnym stosunkiem do życia. Wartość refleksji Etty Hillesum przejawia się głównie w zaakcentowaniu właśnie tej strony życia, której nie da się zredukować łatwo do „efektu” śmierci, a więc tej, która sięga o wiele dalej, do dialogu z Bogiem, którego sens polega między innymi na tym, iż jest zanurzony w obietnicy kontynuacji w wieczności. Niekonwencjonalność myśli Etty Hillesum w dużej mierze zdaje się także polegać na tym, iż sam rytm pisania oraz dobór narracji do opisu kolejnych doświadczeń nie cechuje się jasną metodologią, ale fakt ten nie umniejsza możliwości podążania za jej oryginalnym sposobem ujmowania rzeczywistości człowieka (zarówno tej wewnętrznej, jak i zewnętrznej) i w owym podążaniu dostrzeżenia specyficznego duchowego procesu, rozgrywającego się w autorce pamiętników, przebiegającego na osi od bycia „pustym naczyniem, przez które sączy się życie” [Hillesum 2013, s. 41], aż do poczucia wolności, objawiającej się w modlitwie życia, w modlitwie do Boga i o Boga i wreszcie w modlitwie samej wolności ${ }^{2}$, która nie traci przez złowieszczą siłę śmierci, ale swą mocą jest w stanie stawić jej opór.

W pamiętnikach Etty Hillesum jak w soczewce skupiają się antynomiczne doświadczenia: codzienności i prób wyrwania się z niej, życia w wolności i bez niej, afirmacji życia i jego negacji, naturalności i nienaturalności rozmaitych stanów wewnętrznych, zwycięstw i przegranych, patetyczności i zwyczajności. A wszystko ma swą proweniencję w samym ujęciu podmiotu człowieka jako „nie mieszczącego się w żadnym psychologicznym wzorze” [Hillesum 2013, s. 43]. Szukając własnej tożsamości i czyniąc własne wnętrze, jak sama określa, „polem bitwy” [Hillesum 2013, s. 42] o siebie, nie zamyka się w monadycznym opisie stanów emocjonalnych i przeżyć, ale widzi w tym szerszą perspektywę, a nawet konieczność otwarcia tej duchowej przestrzeni innym. Nie można przy tym zarzucić autorce duchowego ekshibicjonizmu czy swego rodzaju neurotycz-

\footnotetext{
${ }^{2}$ Niejednoznaczne wyrażenie ,modlitwa wolności” nie jest tu rozumiane li tylko jako metafora czy personifikacja wolności, w której przejawia się istota człowieka, lecz ma na celu zwrócenie uwagi na skupiony, subtelny proces intelektualnych i duchowych poszukiwań człowieka, zawsze płynący swoistym strumieniem myśli, uczuć i indywidualnych refleksji. Wyrażenie to może również oddawać rzeczywistość obrania określonej drogi przez jednostkę, w której wolność niejako osiąga pełną i autentyczną postać dopiero w szczerej modlitwie i kontemplacji Boga. Wolność w modlitwie i modlitwa w wolności są strumieniem, w którym uobecnia się życie. Warto podkreślić, iż nie tylko człowiek w swej wolności może się modlić, ale w pewien sposób i sama wolność skierowana ku Bogu „,modli się” w człowieku.
} 
nego wyrzucania z siebie rozmaitych treści w poszukiwaniu ulgi czy kompensacji, ponieważ w wielu miejscach przewija się i przejawia wielka tęsknota za wolnością ludzkości i prawdziwym życiem osobowym człowieka. Wprawdzie język Etty Hillesum wielokrotnie charakteryzuje patetyczność (np. rozmyślania nad „cierpieniem ludzkości”, kontakt z „historią świata”), ale sama przyznaje, na czym jej najbardziej zależy i co jest podstawowym celem jej refleksji, a mianowicie chodzi o „stworzenie w sobie wielkiej, rozległej równiny, pozbawionej zdradzieckich chaszczy, które utrudniają widok - tak, aby coś z «Boga» zamieszkało we mnie, podobnie jak mieszka w IX Symfonii Beethovena, tak, aby zagościło we mnie coś z «miłości», ale nie tej luksusowej na pół godziny, w której z lubością się zanurzam, dumna z własnych podniosłych uczuć. Chodzi raczej o miłość, która znajduje zastosowanie w drobnych sprawach codziennego życia" [Hillesum 2013, s. 39].

\section{Rys antropologiczny w refleksji Etty Hillesum}

Obraz człowieka wyłaniający się z zapisu zawartego w pamiętnikach podkreśla zarówno dualizm osoby ludzkiej (złożenie z duszy i ciała), jak i jego dialektyczny charakter, rozgrywający się w wymiarze wolności, emocjonalności, duchowości i racjonalności. W ujęciu Hillesum byt ludzki wyposażony w wolność toczy nieustanny bój o siebie. Walka ta rozgrywa się w różnych fazach, przybierając sinusoidalny kształt, ale zawsze chodzi w niej o samego człowieka, a precyzyjniej o samozrozumienie, samopoznanie, a poprzez nie o coraz pełniejsze rozumienie innych i Boga. Drogą do zrozumienia siebie i głębszego wnikania w istotę tego, kim się jest, można by rzec, jest sokratejskie „zaglądanie do środka”, bo tylko tam gdzieś na dnie leży przybliżenie tego, kim i jakim człowiek jest i się staje. W widoczny sposób Etty Hillesum staje się reprezentantką takiego sposobu bycia i dążenia do zgłębienia prawdy o sobie, który preferuje drogę ,wewnętrzną” jako pewniejszą, mimo iż niebezpieczną, wyboistą i trudną. Poprzez autorefleksyjny sposób opisu doświadczeń wydaje się, że Etty Hillesum odsłania po raz kolejny w historii człowieka możliwość przypatrzenia się jednostce jako takiej, uwydatniając jej ogólnohumanistyczny rys, a wraz z nim ogólnohumanistyczne przesłanie. Byt ludzki w opisie Hillesum jawi się nie tylko w swym uwarunkowaniu biologicznym, ale również wyraźnie w swym uwarunkowaniu ontologicznym, na wskroś przenikniętym religijnością jako nieodłączną sferą „wewnętrzności” człowieka. Człowiek nie tylko przeżywa swój los na sposób wewnętrzny, ale przede wszystkim kształtuje go od wewnątrz. Ma zatem możliwość wpływania na swój los i alternatywnego potraktowania własnego sposobu wybierania wartości. Człowiek „wewnętrzny” w sposób wolny ma możliwość zarówno kształtowania siebie, 
jak i w owym kształtowaniu ukierunkowywania swej woli. Wolność ma tu tę na wskroś wyraźną właściwość, iż każdy człowiek , urabia własny Schicksal, los od wewnątrz" [Hillesum 2013, s. 101], a zatem w niepowtarzalny i oryginalny sposób skorzysta z wolności, jaką posiada, w określonym kierunku, celu i kresie.

Konwencja wydanych pamiętników dzieli symbolicznie opis doświadczenia człowieka na co najmniej dwie części: pierwszą, którą można nazwać psychologiczną, opisującą życie Hillesum, gdzie czytelnik dowiaduje się o jej różnorodnych zmaganiach wewnętrznych nie tylko w kontekście toczącej się wojny i realizacji nazistowskiego „doskonałego planu”, ale przede wszystkim w kontekście codzienności, w jakiej żyje i pracuje, gdzie ma się wgląd w intymne sfery przeżywanej miłości do $\mathrm{S}^{3}{ }^{3}$, w jej zainteresowania badawcze i estetyczne (zwłaszcza literaturą i kulturą rosyjską: Puszkinem, Dostojewskim, ale też myślą św. Augustyna, Rilkego, Biblią oraz dziełami Leonarda i Michała Anioła), a także wiele rozterek duchowych związanych z poszukiwaniem Boga. Część druga natomiast (mistyczno-duchowa) jest poświęcona stałemu poszukiwaniu Boga, w niej też coraz mocniej dochodziło do głosu wołanie o żywy kontakt z Bogiem, którego - jak sama podkreślała - często „zakopywała” i trzeba było Go na nowo „wygrzebać”. Pracowała wówczas jako maszynistka w obozie przejściowym w Westerborku, szerząc oświatę wśród współrodaków ${ }^{4}$. W tym też okresie pamiętniki cechuje dojmujące napięcie piętrzących się paradoksów: dostrzegania piękna życia mimo wielu obliczy jego brzydoty, poczucia wolności mimo zewnętrznego zniewolenia, odczuwania przebaczenia mimo budzącej się w wielu ludziach chęci zemsty, wzbudzania w sobie ufności i wdzięczności mimo dostrzegania niesprawiedliwości, zauważania w sobie błędów w nieustannym doświadczania zła ze strony innych, uwydatniania jasnych cech osoby ludzkiej mimo szerzącej się wokół ciemności i okrucieństwa jej zachowań.

Należy zaznaczyć, iż obie części: psychologiczna i mistyczno-duchowa stanowią kontinuum i wzajemnie się przenikają, nie wytwarzając sztucznego podziału życia Etty Hillesum na jakieś „przed” i „po”, lecz ukazując wielkie bogactwo życia człowieka, kobiety, która stwierdziła: „gdybym dowiedziała się, że jutro mam umrzeć, powiedziałabym: «Prawdziwa szkoda, ale było dobrze, tak jak było»" [Hillesum 2013, s. 30].

Warstwa wewnętrzna i jej ciągła dialektyka rozgrywają się w samotności. To właśnie pojęcie samotności (samo w sobie oscylujące między pozytywnymi

\footnotetext{
${ }^{3}$ Etty Hillesum preferuje tę formę zapisu, kiedy przedstawia swoje najgłębsze doznania i uczucia względem ukochanego.

${ }^{4}$ Posiadała specjalną przepustkę, która upoważniała ją do kursowania między Westerborkiem (skąd wieziono dalej jeńców do Auschwitz) a Amsterdamem. Do Auschwitz trafiła 7 września 1943 r. przez deportację wskutek odmowy przez jej brata skorzystania ze statusu „cultuur-jood” i z całą rodziną została zamordowana po dwóch miesiącach.
} 
i negatywnymi jej aspektami) staje się czymś bardzo potrzebnym, nieomal koniecznym w procesie duchowego rozwoju i uzyskiwania coraz większej wewnętrznej wolności. Uczyć się wolności w gruncie rzeczy można jedynie przez bycie samotnym i samotność w sobie pielęgnującym. Przeto obszar samotności staje się rezerwuarem wielu konfiguracji przemyśleń, stanów i przeżyć, przez co w takim oddzieleniu od wszystkiego, co zewnętrzne, można dopiero zrozumieć, co jest sensem życia. Etty Hillesum sama wyróżniała w sobie dwa rodzaje samotności: tę, która ją unieszczęśliwiała i wpędzała w pustkę, oraz tę, która uszczęśliwiała i prowadziła do coraz jaśniejszego widzenia rzeczywistości. Oba rodzaje skoncentrowane w podmiocie współistnieją i dają o sobie raz po raz znać, ale tylko drugi prowadzi do pełnego wyzwolenia oraz poczucia jedności z każdym innym oraz z Bogiem [Lebeau 2000].

Co może być kluczem do uwydatnienia antropologicznego rysu myśli zawartej w pamiętnikach? Wydaje się, że co najmniej trzy zasadnicze wątki mogą stanowić pewną strukturę wizji człowieka w refleksji Etty Hillesum. Są nimi: pozytywna, ale i realistyczna koncepcja człowieka jako bytu zanurzonego w nadziei, dostrzegającego siłę w swoich możliwościach, umiejącego transcendować własne żądze w kierunku czynów szlachetnych i twórczych, wątek miłości ku Bogu i innym i wreszcie wątek wolności jako tej, która funduje coraz pełniejsze stawanie się sobą. Etty Hillesum w wielu miejscach swych refleksji podkreśla drogocenność człowieka oraz jego powołania, które z pewnością nie polega na błędnym kole nienawiści, ponieważ „pragnienie zemsty jest zbyt wygodnym uczuciem” [Hillesum 2013, s. 100].

Na uwagę zasługuje istotny element pracy nad sobą w kształtowaniu własnego losu. Kiedy Etty Hillesum mówi, że „zgnilizna innych jest w nas”, wskazuje na kierunek w myśleniu człowieka o sobie. Pierwszym etapem ma być analiza własnej wewnętrznej przestrzeni, a dopiero później ewentualne podsumowywanie zachowań u innych i wydawanie sądów. Etty Hillesum preferuje ostatecznie oddalanie się od dostrzegania u innych zła i zgnilizny moralnej, widzi w tym bowiem spiralę potencjalnej nienawiści i niesprawiedliwości. Nie jest możliwa zmiana świata i innych, zanim nie dojdzie do zmiany samego siebie. Etty Hillesum obiera drogę dawania świadectwa własnym życiem. Sądzi, że jedynie ten sposób na ulepszanie rzeczywistości może wnieść w nią nową jakość. Rzecz jasna, że możliwość zmiany siebie nie może sztucznie negować otaczającego i zagrażającego zła, ponieważ „koszmary kryją się blisko nas, tkwią w nas i wypływają z nas, przez co wydają mi się bardziej swojskie, a mniej upiorne" [Hillesum 2013, s. 102]. Mimo to jednak myślicielka afirmuje życie w jego pełni. Wiedząc o realiach nagonek, aresztowań, śmiertelnych przesłuchań, gwałtu i terroru obozów koncentracyjnych, zarazem niemalże poetycko i lirycznie opisuje doświadczenie życia: „, [...] czułam, jakby życie ze wszystkimi swoimi tajemnicami stało tuż przy mnie, tak że prawie 
mogłam po nie sięgnąć. Odpoczywałam na jego nagiej piersi i wsłuchiwałam się w delikatne regularne bicie jego serca. Leżałam w objęciach życia i czułam się bezpiecznie. [...] Staję oko w oko z każdym fragmentem rzeczywistości, która się we mnie wdziera. Mimo to - w chwili nieuwagi i pozostawiona samej sobie - nagle spoczywam na obnażonej piersi życia, czując jego delikatne i opiekuńcze ramiona wokół siebie. [...] Tak wygląda siła witalna, która mnie wypełnia, i wierzę, że żadna wojna czy bezsensowne ludzkie okrucieństwa - jakiekolwiek by one nie były - nie są w stanie tego zmienić" [Hillesum 2013, s. 112-113].

Pokłady nadziei i miłości, oddawanie hołdu życiu i twórczości wobec toczącej się wojny nie oznaczały u Etty Hillesum zanurzania się w wirze utopijnych wyobrażeń i fantasmagorii, lecz raczej stanowiły rodzaj duchowego wyswabadzania się z rozmaitych lęków trawiących młodą Żydówkę. Autorka pamiętników wielokrotnie podkreśla dojmujący nacisk zewnętrznych okoliczności, paraliżujące poczucie winy względem współbraci, współcierpienie oraz poczucie rozdźwięku między własną kondycją (egzystencjalną i materialną) a realną sytuacją tych, którzy w tym samym czasie cierpią bezmiar okrucieństwa. Etty Hillesum dostrzega w sobie najmniejsze detale skrajności, kumulujących się i piętrzących, w obliczu których pozostaje albo milczenie, albo próba stoczenia wewnętrznej walki. To jednak, co wydobywa się ponad te skrajności, to przekonanie, że „obok brutalnej rzeczywistości istnieje miejsce dla pięknych marzeń” [Hillesum 2013, s. 111]. Rzecz jasna, iż tego typu ujmowanie własnego losu i widzenia świata nie ma (bo nie może mieć) ambicji uniwersalistycznych, co jednak - jak się zdaje nie umniejsza wkładu, jaki Etty Hillesum wnosi w opis doświadczenia człowieka, który żyje i funkcjonuje w czasie wojny, sama nie mając (jeszcze) doświadczenia obozowego, z samego jego wnętrza, przez co z góry skazana jest na „zewnętrzną” formę obserwacji zdarzeń. Autorka pamiętników jest cały czas świadoma absurdalności ideologii zagłady, ale nie jest bezczynna. Wprawdzie sama o sobie mówi, że „nie nadaje się na działaczkę społeczną i politycznego wywrotowca” [Hillesum 2013, s. 116], ale dostrzega w sobie inny rodzaj bezkompromisowej walki o siebie i innych. Jest nią swoista modlitwa, która najpierw „poszukuje wokół siebie tworzywa, aby udowodnić przyczynę własnego istnienia" [Hillesum 2013, s. 118], a potem poprzez nieustanną pracę człowieka nad sobą zamienia się w miłość do bliźnich i Boga. Etty Hillesum jest przeświadczona o tym, iż gromadząc duchowe bogactwo w czasie, nie robi tego dla siebie, lecz dla innych, nawet jeśli mogłoby się zdawać, że w tym samym czasie powinna działać zupełnie inaczej. Można stwierdzić, iż własną drogę życia (powołanie, misję) pojmuje dość jasno jako wykorzystanie każdej najmniejszej chwili na pisanie, samokształcenie, rozwój duchowy, by móc później dzielić się tym z innymi. Jak sama pisze, „ma zobowiązania natury moralnej” [Hillesum 2013, s. 123]. 


\section{Rozważania o śmierci i przebaczeniu}

Znamienny i ważny moment w rozmyślaniach Etty Hillesum zajmuje krótka konstatacja dotycząca natury relacji personalnych między poniżanym i poniżającym w kontekście eksterminacji narodu żydowskiego. To, jak Hanna Arendt (sama będąc żydowskiego pochodzenia) po wojnie radykalnie określiła Żydów mianem „zasłużenie pogardzanego narodu” [Arendt 2012, s. 269], znajduje swój wyraz i w myśli Etty Hillesum, która zauważała taki rodzaj bierności narodu żydowskiego względem prześladujących go nazistów, który paradoksalnie wywoływał i prowokował do traktowania jego przedstawicieli jako poniżających się w tych okolicznościach, a zatem jako ludzi, którzy z braku szacunku do samych siebie niejako „zasługują” na szykany, tortury i śmierć. W relacji tego, kto poniża, i upokorzonego zachodzi specyficzny ruch woli: ten, kto daje się i pozwala upokorzyć, tym samym chce się upokorzyć. Przyzwala on zatem na to, co upokarzający w nim wywołuje. Owo przyswojenie np. upokarzającego gestu jest jednocześnie aktem dobrowolnego „przysposobienia” narzuconej antywartości i odtąd jakby uczynienia jej swoją, a co za tym idzie, uległości względem upokarzającego. Konsekwencje gestu upokorzenia drugiego mogą być różnorodne, zarówno psychologiczne, jak i moralne. Upokarzający, odnosząc swoistą przewagę nad upokorzonym, może czuć satysfakcję, może też odczuć w sobie przyzwolenie na zachowania tego typu w przyszłości o jeszcze bardziej wysublimowanych formach, może też dojść do zanegowania w sobie destruktywnej strony tego aktu, jako w zasadzie pożądanego, bo przynoszącego określone „korzyści”. Zatem bierność drugiej strony, czyli tego, kto pozwala się sprowadzić do roli upokorzonego, może wręcz zachęcać do eskalacji takiego sposobu traktowania przez oprawców. Etty Hillesum sądzi, że jedynie odporność na upokorzenie (obecne w geście, słowie, czynie, aluzji itp.) może być skutecznym oporem służącym nie tylko do zachowania własnej godności, ale także do ukazania wewnętrznej niezłomnej siły, której nie jest w stanie podeptać żaden człowiek, a przez to również odbieranie przeciwnikom pewności, iż mają stałą kontrolę nad uległym. Etty Hillesum wierzy, że efekty poniżania spełzłyby na niczym, gdyby się im w taki sposób przeciwstawiać. Pisząc o tym, zauważa więc coś specyficznego w zachowaniu własnego narodu, co godziło w niego samego. „To my sami - stwierdza - popełniamy największy rabunek", okradając się z tej siły, której brak na dodatek przekształca się w nienawiść i „bufonadę maskującą strach” [Hillesum 2013, s. 123]. Konstatuje więc wprost: „należy wychowywać Żydów”, gdyż „,nawet nad tą drogą, która nam pozostała, wisi całe niebo. Nie mogą nam nic zrobić, naprawdę nic" [Hillesum 2013, s. 123].

Co istotne, jako holenderska Żydówka, wiedząca dokładnie, co dzieje się z rodakami idącymi do transportu, i mająca przekonanie, że w każdej chwili 
może się przydarzyć to także jej i jej bliskim, nie jest wyrazicielką pytania ,gdzie jest Bóg, skoro możliwy jest Holokaust?” lub „gdzie jest Bóg, kiedy zagazowuje się ludzi w Oświęcimiu?", zadawane przez wielu w tamtym czasie i po wojnie. Przeciwnie, Etty Hillesum przejmująco stwierdza, iż to „nie Bóg jest nam winien przeprosiny, ale my jemu. [...] Bóg nie jest odpowiedzialny za ten bezsens, który sami sobie stwarzamy, to my ponosimy winę. Wiem, że w tysiącach obozów koncentracyjnych umarło już tysiące ludzi, mam tego świadomość i kolejne informacje nie wywołują u mnie niepokoju. W ten czy inny sposób już to wszystko wiem. A jednak nadal uważam, że życie jest piękne i głębokie. W każdej minucie" [Hillesum 2013, s. 130]. Stąd życie nabiera formy wszechogarniającej modlitwy, mimo dojmującej rzeczywistości, ciążącej przede wszystkim na wszystkich znajdujących się na liście śmierci. Etty Hillesum nieustannie podkreśla, że bliskość Boga i bliskość z Bogiem są tym, co przekracza wszelki lęk, daje nadzieję na maksymalne wykorzystanie tego czasu, który został podarowany: „A ja wierzę w Boga, nawet jeśli wkrótce w Polsce zeżrą mnie wszy" [Hillesum 2013, s. 131]. Postawione pytanie: „,czy każdego dnia nie przeżywamy całego życia?” [Hillesum 2013, s. 132] niejako kumuluje w sobie sens życia i śmierci, trwania i przemijania, rozumiane jako w gruncie rzeczy stanowiące jedność. To, co w życiu cenne, nie sprowadza się zatem jedynie do jasnej jego strony, ale paradoksalnie musi mieć w nim miejsce i to, co ciemne, to, co niesie cierpienie, by człowiek dostrzegł ostatecznie blask samego życia jako wartego, by je przeżyć. Etty Hillesum postrzega cierpienie jako wpisane w ludzką kondycję, chociaż częstokroć jego bezsensowność odziera człowieka z poczucia sensu. Myślicielka właśnie sens widzi w tym, iż mimo że „chodzi o nasz koniec i zagładę” i „nie ma co robić sobie większych iluzji”, to nawet ,jeśli pójdziemy do diabła, to z największą gracją, na jaką nas stać" [Hillesum 2013, s. 133-134]. Akceptacja własnego losu jawi się tu jako zwycięstwo człowieka i być może najwyższy przejaw jego wolności. Tak więc Etty Hillesum wybiera drogę twórczej akceptacji i wyrabiania w sobie postawy przebaczenia zamiast podsycania w sobie pragnienia zemsty i nienawiści do potencjalnych oprawców. Więcej, dokonuje swoistego rozliczenia się z życiem, bo wówczas „nic więcej nie może mi się przytrafić” [Hillesum 2013, s. 135], przy czym owo rozliczenie nie polega ani na sporządzeniu rachunku zysków i strat, ani na podliczeniu dokonań i zaniedbań, lecz na włączeniu we własną świadomość i całe jestestwo możliwości śmierci, a nawet, jak sama przyznaje, „,wzbogaceniu ich o nią" [Hillesum 2013, s. 135]. Stąd też zaznacza, że nie będzie „zionąć żółcią” do nikogo i nikogo nie będzie też osaczać swoimi troskami, lękami. Chce wieść życie tak dobre, pełne i wiarygodne, jak tylko będzie w jej mocy, ,,aż po ostatnie tchnienie" [Hillesum 2013, s. 134]. Ten projekt na dalsze życie jest ciągłym potwierdzaniem przekonania o wartości życia, o jego sensowności i niezbywalności, nawet jeśli nachalność śmierci wsącza się w krwioobieg całej Europy. 
Śmierci nie należy się hołd ani oddanie jej cząstki życia, ale należy traktować ją jako inherentnie wpisaną i włączoną w istnienie, gdyż przez to odsłania się szersza perspektywa wzbogacenia samego życia i jego rozmaitych odcieni. Śmierć jest ,jak dobra znajoma, która należy do życia i którą musimy zaakceptować. To takie proste, nie trzeba snuć głębokich rozważań na ten temat" [Hillesum 2013, s. 136]. Życie wówczas nabiera zupełnie nowego kształtu, bo usuwa roszczenia, za to otwiera wdzięczność za wszystko, co dobre, piękne i wieczne, bo dostrzega wypierającą zło siłę przemożnego dobra. Nie należy przygotowywać się do śmierci ani na śmierć (na zagładę), ale żyć, ponieważ ,prasiła objawia się w tym, że nawet gdy nadchodzi nasz marny koniec, aż do ostatniej chwili żywimy przekonanie, że istnienie jest pełne głębi i piękności, że ziściliśmy w sobie wszystko, a życie było dobre, takie jakie było" [Hillesum 2013, s. 144]. Zaznajomienie się ze śmiercią nie jest jaką́s próbą jej bagatelizacji, a akceptacja śmierci nie jest ,zaczarowywaniem" jej misterium, lecz wiąże się z poczuciem wewnętrznej wolności, która przekracza to, co skończone. Wykluczenie fizyczne z grona żywych jest czymś o wiele płytszym od posiadania przez człowieka tej niezniszczalnej godności, która siłą wolności nawet w chwili śmierci nie może ulec unicestwieniu. Wtedy też jest możliwe realne doświadczenie tego, że nie jest się w „niczyich pazurach” oraz że poza zniszczeniem fizycznym w gruncie rzeczy nikt nic nie może nam uczynić. Stąd podstawową troską Etty Hillesum w obliczu nazistowskiej zagłady z jednej strony $\mathrm{i}$ wobec poczucia nieuchronności śmierci jako takiej z drugiej strony jest trwanie przy Bogu oraz życie w sposób zgodny z własnym systemem wartości aż po kres, gdyż „nawet jeśli nie przeżyję, to sposób, w jaki umrę, będzie decydujący przy ocenie mnie jako człowieka. Rzecz nie sprowadza się do tego, by w określonej sytuacji uratować się za wszelką cenę, ale do tego, jak postąpić niezależnie od sytuacji i żyć dalej” [Hillesum 2013, s. 159]. Autorka pamiętników wskazuje przez to, że znaczenie ma nie to, że się umiera, ale w jaki sposób się umiera. Etty Hillesum sądzi i za wszelką cenę stara się zakomunikować światu i samej sobie, że żałosny i infantylny sposób umierania jest czymś z punktu widzenia człowieczeństwa destrukcyjnym i oznaczałby kompletne fiasko człowieka; „naprawdę w porównaniu z tym Piekło Dantego jest płochą operetką" [Hillesum 2013, s. 165]. Dlatego sama oświadcza, że będzie ,żyła dalej z tym, co w zmarłych nieśmiertelne, a wskrzesi to, co w żywych umarło" [Hillesum 2013, s. 186].

\section{Rzeczywistość modlitwy oraz siła ducha}

Istotnym i twórczym wątkiem refleksji Etty Hillesum w kontekście życia rozgrywającego się w rozgorzałej wojną Europie jest rodzaj specyficznej rozmowy-modlitwy z Bogiem, która nie tylko dostarcza życiowej siły, energii 
i mądrości, ale również odgrywa ważną rolę w procesie zdobywania duchowej dojrzałości autorki. Przemierzając religijne wątki pamiętników, wcale nie dominujące w całości refleksji, czytelnik spotyka się z oryginalnym sposobem traktowania samego Boga, który jawi się nie jako oddalona bezkreśnie Transcendencja, lecz jako Osoba, z którą dialoguje się tak samo jak z innym człowiekiem. Dialog ten rysuje się jako swoiste przypominanie o sobie Bogu, jako taka dysputa, która ma przeszkodzić Bogu w ucieczce od człowieka [Hillesum 2013, s. 160], a zatem jako coś, co nieustannie komunikuje Bogu o życiu, o Jego trwaniu przy człowieku pomimo monstrualnych niekiedy rozmiarów złego działania człowieka. Etty Hillesum staje w prawdzie o sobie, ale z jednoczesnym zadeklarowaniem pragnienia serca: „Przeżyjesz jeszcze we mnie chude lata, Panie, niekarmiony dostatecznie treściwie przez moje zaufanie, ale uwierz mi, będę nadal dla Ciebie pracować, pozostanę Ci wierna i nie wypędzę Cię z mojego terytorium" [Hillesum 2013, s. 160].

Bóg to ktoś, kto jest gwarantem miłości i jej jedynym, prawdziwym ambasadorem. Dzięki Niemu można podążać własną drogą, dokonywać własnych wyborów, trwać przy nich, a jednocześnie zdobywać szczęście, nie tracąc niczego z siebie. Bóg to byt, o który trzeba się troszczyć, tak samo jak matka troszczy się o dziecko, wszakże „chodzi o to, bym nosząc Cię ze sobą, nie uszkodziła Cię i zawsze pozostała Ci wierna" [Hillesum 2013, s. 170], a poprzez wierność (która nie jest uległością) mogła wypełnić swoje życie zaufaniem, wdzięcznością i pokojem. Najwyższym stopniem ubezpieczenia na życie jest według Etty Hillesum sam Bóg. Troska o wszelkie inne sprawy światowe jest zatem trwonieniem źródła, które człowiek otrzymał w spadku, jest także zasłanianiem światła, które jak lampa oświetla drogę. Jest ono w końcu marnotrawieniem siebie, przygaszaniem drogocennego ognia miłości, mającej się dawać innym. Bóg również odsłania się jako przyczyna twórczości, zarówno artystycznej, jak i twórczości w sferze ducha. Dlatego też wewnętrzne dialogi z Bogiem rodziły się z twórczej energii rozpoznawanej w sobie samej, ale także z pragnienia afirmacji świata i samego życia, które ukonkretniały się w miłości do całego rodzaju ludzkiego, a nie tylko do najbliższych. Odwaga miłości do wszystkich bez wyjątku nie wydaje się jakimś nadętym heroizmem Etty Hillesum czy odmianą utopijnego w niej dziecięctwa, lecz raczej przekonaniem, że miłość jest jedynym kluczem do rozwiązania kwestii człowieka. Pisze ona: „Każdej nowej zbrodni i każdemu koszmarowi przeciwstawiamy dodatkową cząstkę miłości i boskości, którą musimy wydobyć z nas samych. Możemy cierpieć, ale nie wolno nam ulec. Jeśli zarówno nasze ciało, jak i dusza, ale zwłaszcza dusza, przeżyją nietknięte te czasy bez żółci, bez nienawiści, wówczas po wojnie będzie nam przysługiwało prawo, by mieć coś do powiedzenia" [Hillesum 2013, s. 222]. Etty Hillesum nie wyczekiwała śmierci. Pragnęła żyć pełnią życia, antycypując sposób własnego postępowania po 
szczęśliwym zakończeniu wojny. Jednocześnie miała świadomość nieustannego zagrożenia życia i wielokrotnie przedstawiała obraz swoich ostatnich chwil życia z dala od obozu koncentracyjnego, chcąc wyłączyć z życia wszelkie infantylne zachowania i oddając się całkowicie modlitwie, której w zasadzie żadne, choćby najmniejsze pomieszczenie czy jego brak nie mogłoby ograniczyć poruszeń serca ku Bogu. Etty Hillesum posługuje się metaforą fotograficznej kliszy, na której w ostatnie dni na wolności utrwalone zostaną wszelkie detale, momenty i piękno życia jako takiego. Fotografia powoduje jakby zatrzymanie, zastygnięcie tego wszystkiego, co w danej cząstce czasu hibernuje niepowtarzalność, obecność, wszelki przejaw życia, faktyczność rzeczywistości, czyli to wszystko, co w przyszłości będzie miało walor historyczny, w przypomnienie tego, co ważne, co miało miejsce i co się autentycznie wydarzyło. Stosując metaforą kliszy, nie ucieka ona w melancholię przyszłości, lecz raczej postrzega siebie w kontekście przyszłego świadka wydarzeń, o których następnym pokoleniom trzeba będzie zdać relację na podstawie owych wywołanych zdjęć; trzeba będzie opowiedzieć i zaświadczyć o wydarzeniach, które utrwaliła klisza.

\section{Zakończenie}

Podstawowym dylematem wolności w kontekście eksterminacji stało się pytanie stawiane przez Etty Hillesum samej sobie: czy myśleć należy najpierw i przede wszystkim o własnym ocaleniu, czy też poświęcić się dla innych? Z tym dylematem wiązał się też problem, czy z cierpienia można czerpać siły. Etty Hillesum uzasadnia drogę obumierania dla innych, gdyż koncentrowanie się na sobie, własnych słabościach, bólach, niedostatkach zamyka człowieka w obrębie histerycznego poszukiwania za wszelką cenę wyjścia z (w gruncie rzeczy) dość beznadziejnej sytuacji. Akt poświęcenia się innym trzeba odgraniczyć od całkowitego zatracenia się. Dać się innym oznacza wykonywanie potrzebnych czynności, by im pomóc, czy trwanie w gotowości do podjęcia potrzebnych działań, ale nie musi polegać na utracie własnej tożsamości czy wyrzeczeniu się siebie i własnych marzeń. Należy po prostu w najdrobniejsze czynności wpuszczać „okruch wieczności”, usensowniający bezinteresowny dar z siebie innym, gdyż podstawowym zadaniem obozowego życia ma stać się sprawienie, by „pośród cuchnących oparów naszych ciał, nasze dusze ładnie pachniały" [Hillesum 2013, s. 128]. Ponadto wolny dar z siebie jest o wiele silniej umotywowany i trwały niż to, co zostało skądś narzucone pod presją czy przymusem. Kiełkowanie postawy poświęcenia dla innych wewnętrznie wyzwala i uzdalnia jednostkę do większych rzeczy.

Czy Etty Hillesum reprezentuje jakiś rodzaj mistycyzmu? Sama pisze, że w życiu wiele próbuje się ratować za pomocą mętnego mistycyzmu, a przecież 
sama „mistyka musi opierać się na kryształowej uczciwości. Począwszy od zgłębiania istoty rzeczy, a skończywszy na nagiej rzeczywistości” [Hillesum 2013, s. 121].

Ponieważ poza religią chrześcijańską w zasadzie nie istnieją kobiece opisy doświadczeń mistycznych, zapewne trudno jednoznacznie określić, czy to, co opisuje autorka pamiętników nosi znamiona mistyczne. Figury, które stosuje w opisie własnych doświadczeń i przeżyć wewnętrznych, mogą jednak przybliżać do intuicji, iż budowanie szczególnie intymnej relacji z Bogiem odsłania specyficzną przestrzeń funkcjonowania człowieka w świecie na sposób „wewnętrzny”, a kształtowanie własnej duszy od wewnątrz może prowadzić do pełniejszego zrozumienia siebie i własnego powołania. Przedmiotem niniejszego opracowania nie było przeto wykazanie, iż Etty Hillesum jest jedną z większych mistyczek XX wieku, lecz ukazanie kobiety skierowanej w modlitwie wolności ku Transcendencji, której zawierzyła całe swoje 28-letnie życie, drastycznie przerwane w Auschwitz 30 listopada 1943 r.

Oddajmy raz jeszcze głos autorce pamiętników, z którego wydobywa się esencja fundamentalnej afirmacji życia: ,[...] jedną rzecz wiem już teraz z całą pewnością. Nigdy nie będę w stanie ukazać wszystkiego tak, jak to zrobiło samo życie - na moich oczach - za pomocą własnych żywych liter" [Hillesum 2013, s. 193]. „Ale teraz jestem na powrót tylko sobą, Etty Hillesum - pilną studentką w przytulnym, wypełnionym książkami pokoju, w którym stoi wazon margerytek. Moje życie biegnie swoim wąskim korytem, a kontakt z «ludzkością», «historią świata», «cierpieniem» został przerwany" [Hillesum 2013, s. 42].

\section{Literatura}

Arendt H. [2012], Rahel Varnhagen. Historia życia niemieckiej Żydówki z epoki romantyzmu, przeł. K. Leszczyńska, Pogranicze, Sejny.

Gogacz M. [1985], Filozoficzne aspekty mistyki. Materiały do filozofii mistyki, ATK, Warszawa.

Grygiel S. [2011], Jestem, więc modlę się, Flos Carmeli, Poznań.

Hillesum E. [2013], Przerwane życie. Pamiętniki 1941-1943, WAM, Kraków.

Kłoczowski J.A. OP [2001], Drogi człowieka mistycznego, Wydawnictwo Literackie, Kraków.

Lebeau P. SJ [2000], Duchowa droga Etty Hillesum (Amsterdam 1941 - Oświęcim 1943), tłum. B. Piotrowska, http://mateusz.pl/goscie/zd/22/zd22-09.htm (dostęp: 30.12.2015).

Perillo D. [2014], Etty Hillesum. Myślace serce obozu, „Ślady”, nr 1 (styczeń/luty), http://www.slady.pl/artykul.php?art=985 (dostęp: 30.12.2015).

Tarnowski K. [2005], Ustyszeć niewidzialne, Instytut Myśli Józefa Tischnera, Kraków.

Węgrzynowicz L. [2013], Mistyka kobieca. Hermeneutyczne studium kobiecego doświadczenia Boga, Wydawnictwo Naukowe Uniwersytetu Papieskiego Jana Pawła II w Krakowie, Kraków. 


\section{The Prayer of Freedom and Contingency of Human in Etty Hillesum's Diaries (Abstract)}

The experience of freedom, treated in various ways by philosophy, psychology, sociology, theology and politics, is shown as an infinite category. Its complexity and problematic matter is concerned not only with unlimited intellectual interpretations but also with the ways it is treated. From various ways of revealing the phenomenon of freedom, in the context of human contingency, the way of dialogue is prominent, which reveals one of the most important traits which freedom is.

The original reflection, included in Etty Hillesum's diaries (An Interrupted Life) reveals the basic feature of freedom: its relatedness, the deepest expression of which is achieved through one's relationship with God. Through this feature, the trait of the human him- or herself is shown as he or she is able to direct him- or herself towards love or hate, life or death, beauty or ugliness, good or evil. Etty Hillesum herself is for life as it is, and she becomes the real ambassador of life through vertical relations with God, even in the face of extreme danger, injustice and the cruelty of war. In this context, life is not treated as the dominant and oppressive contingency but as a time of kairos, which means something that can be creatively and positively used to make human values and become a witness of life fulfilled by the element of eternity.

In this light, the main goal of this study is to present a few basic threads of the description of humanity, as extracted from Hillesum's self-reflective writing. By delving into the description of Hillesum's inner world, an attempt is made to characterise those elements in the subjectivity of the human, which emphasises the specific individuum as being immersed in relations with himself, others and God.

Keywords: freedom, life, love, God. 